\title{
Protecting Mining Environments from Blasting through Impact Prediction Studies
}

\author{
Bright Oppong Afum ${ }^{*}$, Afia Fima Baah Opoku² \\ ${ }^{1}$ University of Mines and Technology, Tarkwa, Ghana \\ ${ }^{2}$ Newmont Ghana Gold Limited, Airport Residential Area, PMB, Accra, Ghana \\ Email: ^boafum@umat.edu.gh, modfima81@yahoo.com
}

How to cite this paper: Afum, B.O. and Opoku, A.F.B. (2018) Protecting Mining Environments from Blasting through Impact Prediction Studies. Journal of Geoscience and Environment Protection, 6 , 121-132.

https://doi.org/10.4236/gep.2018.65011

Received: January 17, 2018

Accepted: May 20, 2018

Published: May 23, 2018

Copyright $\odot 2018$ by authors and Scientific Research Publishing Inc. This work is licensed under the Creative Commons Attribution International License (CC BY 4.0).

http://creativecommons.org/licenses/by/4.0/

\begin{abstract}
A surface gold mine wishes to develop a new pit (Pit A) as part of its mining schedules. The proposed pit outline is about $300 \mathrm{~m}$ to the closest community. Blasting operations in Pit A would potentially create undesirable environmental impacts including fly rocks, ground vibrations and air blasts to neighbouring communities. Integration of proper planning tools or protocols for blasting at Pit A is the major concern of the Mine. Due to safety reasons, management wishes to explore the best blasting protocols that will restrain any blast impact to a $250 \mathrm{~m}$ buffer from the proposed pit outline. The Kuz-Ram fragmentation model was used to generate the optimal geometric parameters required for blasting at Pit A. Ground vibration, air blasts and fly rock impact prediction models were used to estimate the associated blast impacts to the neighbouring community. The predictions were made for blasting the oxides, transition and fresh rock formations to be encountered in Pit A. The predicted ground vibration and air blast levels were compared with the Ghanaian regulatory threshold of $2 \mathrm{~mm} / \mathrm{s}$. The predicted maximum fly rock distance $(235 \mathrm{~m})$ from the pit outline is within the established $250 \mathrm{~m}$ clearance buffer zone. The geometric drill and blast parameters and associated single-hole firing charges were used in the prediction models. The predicted results from this study will assist the surface gold mine to properly execute safe blasting operations with minimal impact to the neighbouring community. Due to known scattering of NONEL explosives in initiation systems, electronic initiation systems are recommended for blasting in the new pit.
\end{abstract}

\section{Keywords}

Blast impacts, Explosives, Blasting, Impact Prediction Models, Geometric Parameters 


\section{Introduction}

Planning the extraction of any mineral deposit requires the consideration of several parameters including but not limited to the quantity and quality of the deposit but also the associated impacts of the mining operations. Hard rock mining is associated with drilling and blasting of the rock formation. In designing blasts in a typical greenfield open pit mine, much attention is given to important environmental and operational factors. The blast must ensure optimum results for the prevailing pit design and mining conditions, while minimizing its effects on the environment. In cases where blasts are conducted close to human settlements, many interests are given to but not limited to the effects of fly rock, ground vibration and air blast. Overall blast efficiency is achieved when blast designs and implementations are properly executed to improve fragmentation whilst minimizing blast impacts. Evaluation of current blasting practices and prediction of blast impacts are keys to the understanding and implementation of blasting systems to reduce any associated blast impacts.

XYZ surface mine wishes to develop a greenfield pit (Pit A) which lies within two main communities in Ghana. The nearest settlement to the proposed pit outline is about $300 \mathrm{~m}$. On-bench blasting would create considerable environmental impacts notably fly rocks, ground vibrations and air blasts. This requires that prior measures are taken to minimize or eliminate these impacts on the surrounding settlements during mining operations and conform to the national guidelines. The Ghanaian Minerals and Mining (Explosives) Regulations, 2012 [1] sub section 176 (1) (a) states that "the minimum safety distance between a blast and a person near the blast site is five hundred meters;" and sub section (2) states that "the minimum safety distance for civil works may with permission of the Chief Inspector be decreased if persons will not be endangered by the decrease". Sub section (199) of this regulation specifies that the blast vibration and air blast or air overpressure limits should not exceed $2 \mathrm{~mm} / \mathrm{s}$ and $117 \mathrm{~dB}(\mathrm{~L})$ respectively. The Mine therefore wishes to integrate proper blasting tools and/or protocols to reduce the associated blast impacts when developing Pit A.

Blast impacts prediction studies were therefore conducted for blasting at Pit A. Due to safety reasons; prediction techniques were used to assess the blast impacts on settlement at a safe distance of $250 \mathrm{~m}$ from the pit outline instead of 300 $\mathrm{m}$. The Kuz-Ram fragmentation model was used to evaluate and identify the appropriate geometric drill and blast parameters for the blasting operations of the mine that ensures excellent blast performance (acceptable rock fragment sizes required for the processing plant). The study identifies appropriate measures required for blasting at Pit $\mathrm{A}$ that ensure safe blasting operations. Integration of these measures during blasting operations at Pit A is expedient to the success and peaceful co-existence of the mine in the community.

\subsection{The Study Area}

The gold mining project is located at the south western part of Ghana. The pro- 
posed Pit A is an extension of the active mining area of the existing operations of XYZ Mine. The ore deposit comprises generally north-south trending, steeply west dipping auriferous quartz veins hosted by strongly silica and iron carbonate altered, medium to coarse grained, carbonaceous greywacke. A north-south trending dolerite dyke, dipping sub-vertically to the east cuts the depth extension of the main vein.

In the southern portion of the deposit, a west-northwest to east-southeast trending, steeply south-southeast plunging "dyke-like" granitic intrusion is cut by numerous auriferous quartz veins forming a sheeted vein system. In the north of the deposit, mineralization generally occurs in a single lode, but in the south, the mineralization occurs as two main lodes and a series of narrow stacked lodes around or in the outer margins of the granite intrusion. Current interpretation has the main mineralization event occurring post-granite intrusion and prior to intrusion of the dolerite.

\subsection{Proposed Mining at Pit A}

The total material in bank cubic metres $(\mathrm{bcm})$, which include oxide ore, fresh ore and waste to be mined over the life of the proposed pit (1 year) is estimated as $3.921 \mathrm{Mbcm}$. The pit will be mined with $6.0 \mathrm{~m}$ bench heights over a $3.0 \mathrm{~m}$ mining flitch. The deposit will be mined by conventional open pit mining methods, which will utilise open pit mining equipment as listed in Table 1. The size of the mining fleet has direct effect on the quantity of rock material planned to be blasted (or mined) over the period and the generation of infinitesimal ground vibrations to the environment. It further contributes to the atmospheric impact of mining (dust, noise) in the environment [2].

The Kuz-Ram fragmentation model [3] [4] [5] [6] was used to assess the geometric parameters proposed for blasting at Pit A. The blast geometric parameters for Pit A have been determined for the oxide, transition and fresh rock zones of the encountered rock formations. Table 2 shows the evaluation of the proposed drill and blast parameters for Pit A based on the Kuz-Ram model.

\subsection{Historic Blast Performance}

It was known that, Pit A has similar geological properties as an adjacent active pit of mine XYZ. Due to these similarities, blast performance data obtained from the active pit was used to deduce the blast performance at Pit A. Assessment of historic blast vibration and air blast performances was carried out for the active pit. A total of 144 blasts were monitored and they indicated $85.4 \%$ conformance of ground vibration, and $90.3 \%$ conformance of air blast values compared to the Ghanaian regulatory threshold limits of $2.0 \mathrm{~mm} / \mathrm{s}$ and $117 \mathrm{~dB}$ (L) respectively. The historic blast performance data of the active pit used as a guide for the estimations are summarized in Table 3.

The historic blast performance data shown in Table 3 indicates the maximum, minimum, and average of the measured ground vibration levels, air overpressure 
levels and their associated co-operative charges. The standard deviations of these measurements are further assessed. The historic blast performance data from the active pit were used to establish the site-specific constants in terms of the Rock Transmission Factors (RTF) according to the Gustaffson and the United States Bureau of Mines (USBM) models, and the air pressure referenced from atmospheric pressure (Po). The established site-specific constants for the mine are summarised in Table 4.

Table 1. Proposed equipment to be used for mining at Pit A.

\begin{tabular}{ccc}
\hline TYPE & QUANTITY & APPLICATION \\
\hline Drill Rig & 2 & Blasthole/Production Drilling \\
Liebherr 984 Hydraulic Excavators & 1 & Excavation and Loading \\
Motor Grader & 1 & Grading \\
Track Dozer & 1 & Dozing and Pushing \\
Haulage Truck & 4 & Hauling \\
Explosive Truck & 1 & Bulk Explosives Loading \\
Water Bowser & 1 & Dust Control \\
Service Truck & 1 & Servicing Machine \\
\hline
\end{tabular}

Table 2. Evaluation of the proposed blast geometric parameters for Pit A.

\begin{tabular}{|c|c|c|c|}
\hline PARAMETER & OXIDE & TRANSITION & FRESH \\
\hline Burden (m) & 4.0 & 3.5 & 3.5 \\
\hline Spacing $(\mathrm{m})$ & 4.0 & 4.0 & 3.8 \\
\hline Hole diameter (mm) & 115.0 & 115.0 & 115.0 \\
\hline Bench Height (m) & 6 & 6 & 6 \\
\hline Sub-drill (m) & 0.8 & 0.8 & 1.0 \\
\hline Pattern Type & Staggered & Staggered & Staggered \\
\hline Final Stemming $(\mathrm{m})$ & 3.5 & 3.4 & 3.4 \\
\hline RBS of Blend Explosives & 142.0 & 142.0 & 142.0 \\
\hline $\begin{array}{c}\text { Explosive Type } \\
\text { (Blend - } 30 \% \text { ANPP \& } 70 \% \text { Emulsion) }\end{array}$ & Emunex8000 & Emunex8000 & Emunex8000 \\
\hline Explosive density $\left(\mathrm{kg} / \mathrm{m}^{3}\right)$ & 0.0012 & 0.0012 & 0.0012 \\
\hline Relative Effective Energy & 94.7 & 94.7 & 94.7 \\
\hline Drilling Cost $(\$ / m)$ & 14.25 & 14.25 & 9.69 \\
\hline Explosive Cost $(\$ / t)$ & 930 & 930 & 930 \\
\hline Charge per meter, $\mathrm{Mc}(\mathrm{kg} / \mathrm{m})$ & 12.47 & 12.47 & 12.47 \\
\hline Charge length (m) & 3.3 & 3.4 & 3.6 \\
\hline Mass per hole (kg) & 41.15 & 42.40 & 44.89 \\
\hline Mass above grade $(\mathrm{kg})$ & 31.17 & 32.42 & 32.42 \\
\hline Technical powder factor $\left(\mathrm{kg} / \mathrm{m}^{3}\right)$ & 0.32 & 0.39 & 0.41 \\
\hline Actual powder factor $\left(\mathrm{kg} / \mathrm{m}^{3}\right)$ & 0.43 & 0.50 & 0.56 \\
\hline
\end{tabular}




\section{Continued}

\begin{tabular}{cccc}
\hline Mean size $(\mathrm{cm})$ & 41.39 & 36.13 & 34.68 \\
BCMs per hole $\left(\mathrm{m}^{3}\right)$ & 96.00 & 84.00 & 79.80 \\
Explosives cost per hole $(\$)$ & 38.27 & 39.43 & 41.75 \\
Initiation cost per hole $(\$)$ & 6.83 & 6.83 & 6.83 \\
Drilling cost per hole $(\$)$ & 96.90 & 96.90 & 67.83 \\
Total cost per hole $(\$)$ & 142.00 & 143.16 & 116.41 \\
Explosives cost per BCM $\left(\$ / \mathrm{m}^{3}\right)$ & 0.40 & 0.47 & 0.52 \\
Initiation cost per BCM $\left(\$ / \mathrm{m}^{3}\right)$ & 0.07 & 0.08 & 0.09 \\
Drilling cost per BCM $\left(\$ / \mathrm{m}^{3}\right)$ & 1.01 & 1.15 & 0.85 \\
Total cost per BCM $\left(\$ / \mathrm{m}^{3}\right)$ & 1.48 & 1.70 & 1.46 \\
\hline
\end{tabular}

Table 3. Summarized historic blast performance data of the active Pit.

\begin{tabular}{cccc}
\hline $\begin{array}{c}\text { Number of Blasts } \\
(\mathbf{1 4 4})\end{array}$ & $\begin{array}{c}\text { Co-operative Charge } \\
(\mathrm{kg} / \mathrm{hole})\end{array}$ & $\begin{array}{c}\text { Air Overpressure Level } \\
\mathrm{dB}(\mathrm{L})\end{array}$ & $\begin{array}{c}\text { Vibration Level } \\
(\mathrm{mm} / \mathrm{s})\end{array}$ \\
\hline Maximum & 89 & 125.5 & 2.67 \\
Average & 52.6 & 107.6 & 1.18 \\
Minimum & 10.1 & 98.8 & 0.13 \\
Standard deviation & 19.7 & 5.5 & 0.62 \\
\hline
\end{tabular}

Table 4. Site specific constants for Pit A of XYZ mine.

\begin{tabular}{ccc}
\hline PARAMETER & VALUE & MODEL USED \\
\hline $\mathrm{K}$ & 18.773 & Gustaffson \\
$\mathrm{k}$ & 158.11 & USBM \\
$\mathrm{b}$ & -1.153 & \\
Po & $1.8721 \times 10^{-8}$ & $\mathrm{~dB}(\mathrm{~L})=20 \log \frac{P}{P o}$ \\
\hline
\end{tabular}

\section{Materials and Methods}

The associated open pit undesirable blast impacts are ground vibrations, fly rocks and air blasts or air over pressures. Due to the close proximity and the strong geological correlation between the rock formations at the active and proposed pit, the RTF and Po values deduced from data obtained from the current active pit and the proposed blast design parameters for the new pit were used to estimate the blast impacts when developing Pit A.

\subsection{Ground Vibrations Impact Predictions}

Ground vibrations are generated when some of the explosion energy released into the ground generates vibration waves within the rock [2]. Several formulae (relationships) are available in literature for estimating the vibration level for a 
given site condition, however, the relationships after Gustaffson and the USBM have been widely used [2] [7] [8] [9]. Although, the Gustaffson model was developed in Sweden and the USBM model was developed in the United States of America, according to nation-wide study in the Ghanaian mining companies [7], they have been accepted for use in the Ghanaian mining environment. The Gustaffson model (Equation (1)) and USBM model (Equation (2)) are respectively given as:

$$
\begin{aligned}
& \mathrm{PPV}=K \sqrt{\frac{W}{D^{1.5}}} \\
& \mathrm{PPV}=k\left(\frac{D}{\sqrt{W}}\right)^{b}
\end{aligned}
$$

where PPV = Peak Particle Velocity, $\mathrm{mm} / \mathrm{s} ; W=$ Cooperating Charge, $\mathrm{kg} / \mathrm{hole} ; D$ $=$ Distance, $\mathrm{m}$; and $K, k, b=$ Rock Transmission Factors (RTF).

With the predetermined RTF values (Table 4) and the various cooperating charges, PPV levels have been estimated for various distances from the blast. The estimated PPV levels according to the USBM and Gustaffson's models are respectively shown in Figure 1 and Figure 2. Table 5 shows the predicted PPV at the corresponding distances for the cooperating charge when blasting in the various formations at Pit A using the proposed geometric parameters.

\subsection{Fly Rock Impact Predictions}

When fragmented rock resulting from the detonation of explosive charges is transported over a greater distance than anticipated the throw is called fly rock [2]. The maximum fly rock distance for a specific charge $>0.2 \mathrm{~kg} / \mathrm{m}^{3}$ and the boulder size are estimated according to Lundborg [10] as:

$$
\begin{gathered}
L_{\max }=143 \times d \times(q-0.2) \\
\varnothing=0.1 \times d^{2 / 3}
\end{gathered}
$$

where $L_{\max }=$ Maximum Throw (m); $d=$ Hole Diameter (ins); $q=$ Specific Charge $\left(\mathrm{kg} / \mathrm{m}^{3}\right)$; and $\varnothing=$ Boulder Diameter $(\mathrm{cm})$.

Using Equation (3) the maximum fly rock distance was determined for various blast hole diameters and specific charges based on blast historical records of the Mine. The fly rock model for blasting in Pit A is presented in Figure 3. Substituting the proposed blast hole diameter and specific charges for blasting the various rock zones of the new pit in Table 2 into Equation (3) and Equation (4), the maximum fly rock distances and the associated boulder sizes have been predicted and presented in Table 6 . The predicted fly rock distances for blasting the various rock zones of the pit are within the $250 \mathrm{~m}$ clearance buffer, and hence although the $300 \mathrm{~m}$ buffer neighbouring settlement is less than the established $500 \mathrm{~m}$ regulatory clearance buffer for surface blasting operations, the Chief Inspector of Mines could grant permit for mining pit A according to L.I.2177 [1] sub section 176 (2). 
Table 5. Predicted PPV values for blasting at Pit A.

\begin{tabular}{|c|c|c|c|c|c|c|}
\hline \multirow{2}{*}{$\begin{array}{l}\text { Predicted Distance } \\
\text { (m) }\end{array}$} & \multicolumn{3}{|c|}{ USBM Model } & \multicolumn{3}{|c|}{ Gustaffson Model } \\
\hline & $\begin{array}{l}\text { Oxide } \\
(41.1)^{*}\end{array}$ & $\begin{array}{c}\text { Transition } \\
(42.4)^{*}\end{array}$ & $\begin{array}{l}\text { Fresh } \\
(44.9)^{*}\end{array}$ & $\begin{array}{l}\text { Oxide } \\
(41.1)^{*}\end{array}$ & $\begin{array}{c}\text { Transition } \\
(42.4)^{*}\end{array}$ & $\begin{array}{c}\text { Fresh } \\
(44.9)^{*}\end{array}$ \\
\hline 250 & 2.31 & 2.36 & 2.44 & 1.91 & 1.94 & 2.00 \\
\hline 300 & 1.88 & 1.91 & 1.97 & 1.67 & 1.70 & 1.75 \\
\hline 350 & 1.57 & 1.60 & 1.65 & 1.49 & 1.51 & 1.55 \\
\hline
\end{tabular}

${ }^{*}$ Cooperative charges in kg/hole obtained from proposed geometric parameters.

Table 6. Predicted fly rock distances and boulder sizes for blasting at Pit A.

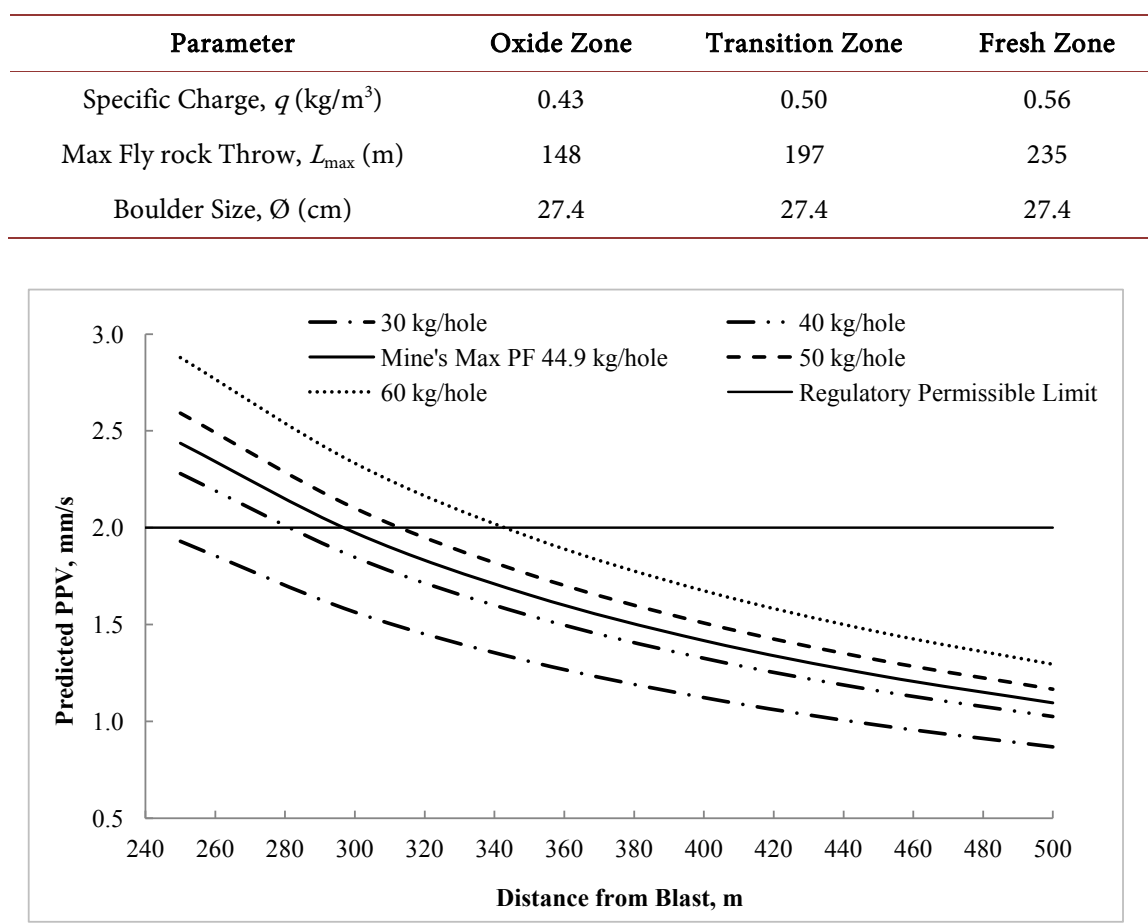

Figure 1. PPV prediction model for Pit A (based on USBM model).

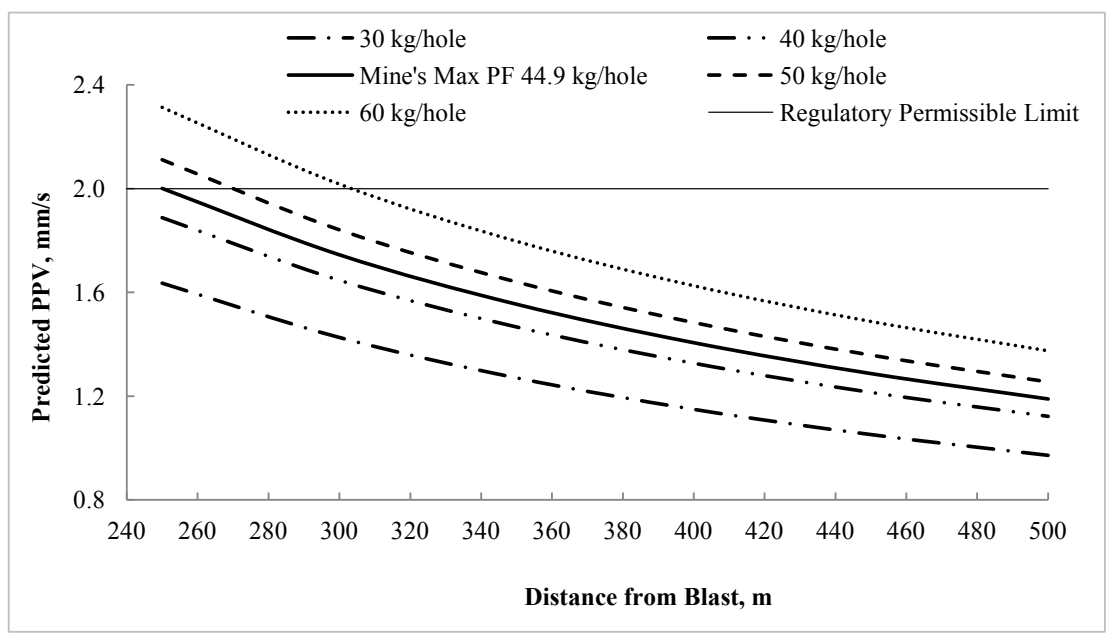

Figure 2. PPV prediction model for Pit A (based on gustaffson's model). 


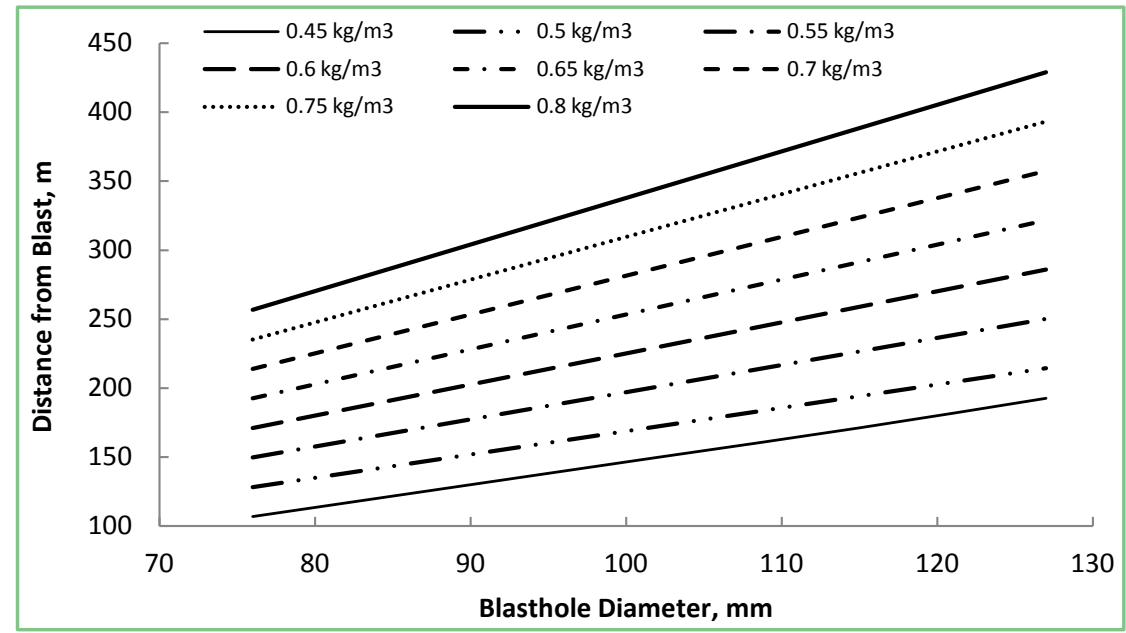

Figure 3. Maximum fly rock throw prediction model for blasting at Pit A.

\subsection{Air Blast Impact Predictions}

One other major blast effect is the generation of considerable air blasts or air overpressures. Unlike ground vibration, air blast seldom causes damage to structures with the resulting associated noise causing a lot of discomfort and annoyance to neighbours. These usually give rise to community agitations [2] and unrest. The air overpressures were predicted according to Rau and Wooten [11], given as:

$$
L p_{2}=L p_{1}-20 \log \frac{r_{2}}{r_{1}}-A e_{1,2}
$$

where $L p_{2}=$ Air Blast for various Distances, $r_{2} ; L p_{1}=$ Air Blast at known Distances, $r_{1}$; and $A e_{1,2}=$ Attenuation Factor (zero in this instance, thus, worst case scenario).

With computed cooperate charges of $41.1 \mathrm{~kg} / \mathrm{hole}$ (for oxides rocks), 42.4 $\mathrm{kg} / \mathrm{hole}$ (for transition rocks) and $44.9 \mathrm{~kg} / \mathrm{hole}$ (for fresh rocks) for blasting at Pit A (Table 2), the predicted air blast at $250 \mathrm{~m}$ based on the average historic cooperate charge of $53 \mathrm{~kg} /$ hole produces $114.7 \mathrm{~dB}(\mathrm{~L})$. This is about $2 \%$ lower than the regulatory permissible limit of $117 \mathrm{~dB}(\mathrm{~L})$. The air blast prediction model based on Rau and Wooten [11], using the average historic cooperate charge of $53 \mathrm{~kg} / \mathrm{hole}$ obtained from blasting operations in the active pit of the Mine adjacent to Pit A is presented in Figure 4.

The air blasts or air overpressures at a blast site may also be predicted using Ollofson [12] and Persson et al. [13] shown in Equation (6) and; Holmberg and Persson [14] shown in Equation (7). However, to convert the air blast or air overpressure from mbar to $\mathrm{dB}(\mathrm{L})$ units, the relationship in Equation (8) is used.

$$
\begin{gathered}
P=0.7 \times \frac{W^{1 / 3}}{D} \\
P=k \times 0.7 \times \frac{W^{1 / 3}}{D}
\end{gathered}
$$




$$
\mathrm{dB}(\mathrm{L})=20 \log \frac{P}{P o}
$$

where $W=$ Cooperating Charge, $\mathrm{kg} /$ hole; $D=$ Distance, $\mathrm{m} ; k=0.75$ for Emulsion Explosives; $P=$ Air Overpressure or Air Blast, mbar; and $P o=$ Air Pressure from Reference Atmospheric Pressure (determined as $1.8721 \times 10^{-8}$ unit less for $\mathrm{XYZ}$ mine site).

Using a maximum cooperating charge of $44.9 \mathrm{~kg} /$ hole from the proposed geometric parameters for blasting fresh rocks at Pit $\mathrm{A}$, the air blast prediction model based on Ollofson [12] and Persson et al. [13] model; and Holmberg and Persson [14] model are shown in Figure 5.

The maximum predicted air blast based on the proposed blast design geometric parameters for Pit A at varying distances are shown in Table 7. It is noted that, the maximum predicted air blast at $250 \mathrm{~m}$ from the proposed Pit A is 114.5 $\mathrm{dB}(\mathrm{L})$. Blasting at proposed Pit A using the proposed drill and blast geometric parameters would not produce air blast values above the regulatory permissible limit of $117 \mathrm{~dB}(\mathrm{~L})$.

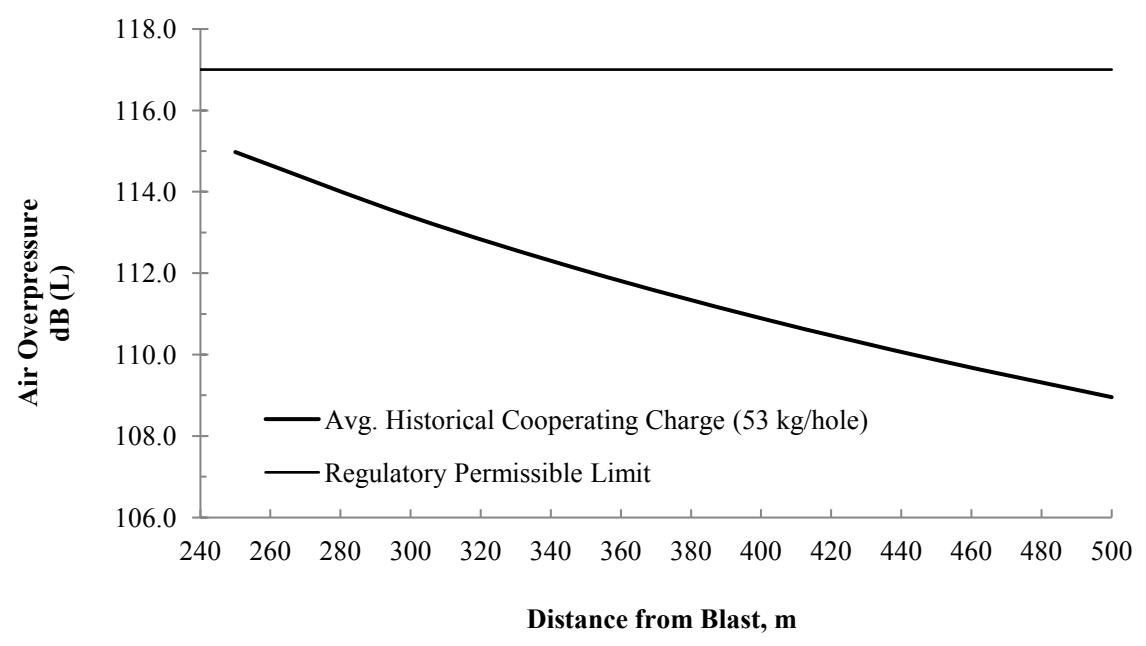

Figure 4. Air blast prediction model for blasting at Pit A (rau and wooten model used).

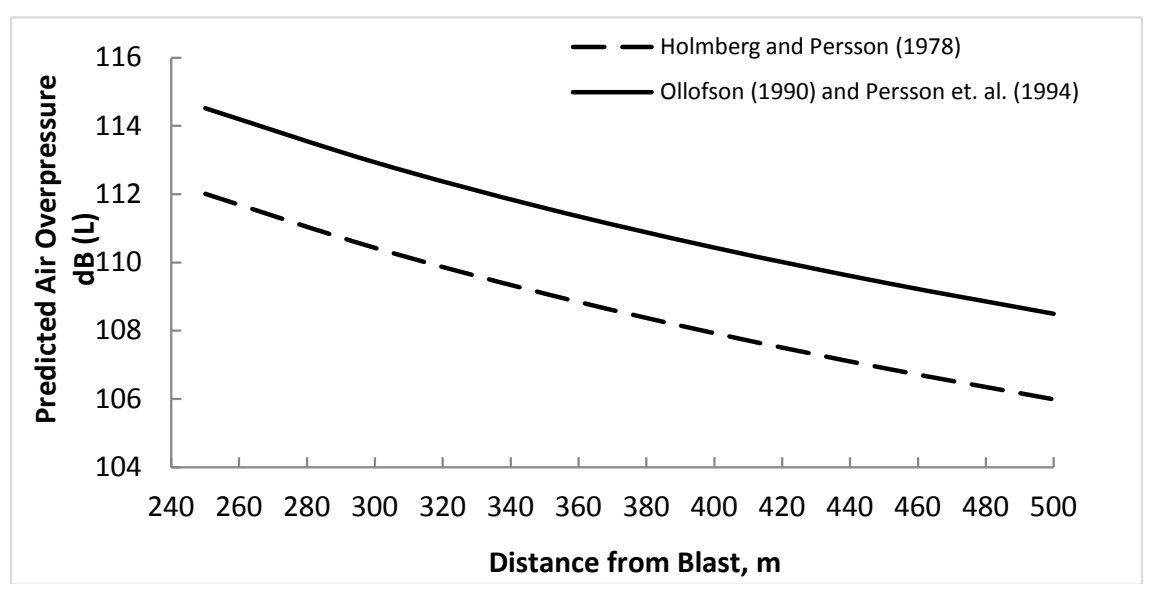

Figure 5. Air blast prediction models for blasting at Pit A. 
Table 7. Predicted air blast for varying distances when blasting at Pit A.

\begin{tabular}{|c|c|c|c|c|c|c|}
\hline \multirow{2}{*}{$\begin{array}{c}\text { Predicted } \\
\text { Distance }(\mathrm{m})\end{array}$} & \multicolumn{3}{|c|}{$\begin{array}{c}\text { Ollofson [12] and Persson et al. } \\
\text { [13] Model }\end{array}$} & \multicolumn{3}{|c|}{ Holmberg and Persson [14] Model } \\
\hline & $\begin{array}{l}\text { Oxide } \\
(41.1)^{*}\end{array}$ & $\begin{array}{c}\text { Transition } \\
(42.4)^{*}\end{array}$ & $\begin{array}{l}\text { Fresh } \\
(44.9)^{*}\end{array}$ & $\begin{array}{l}\text { Oxide } \\
(41.1)^{*}\end{array}$ & $\begin{array}{c}\text { Transition } \\
(42.2)^{*}\end{array}$ & $\begin{array}{l}\text { Fresh } \\
(44.9)^{*}\end{array}$ \\
\hline 250 & 114.3 & 114.3 & 114.5 & 111.8 & 111.8 & 112.0 \\
\hline 300 & 112.7 & 112.8 & 112.9 & 110.2 & 110.3 & 110.4 \\
\hline 350 & 111.3 & 111.4 & 111.6 & 108.8 & 108.9 & 109.1 \\
\hline
\end{tabular}

${ }^{\star}$ Cooperative charges in $\mathrm{kg} / \mathrm{hole}$ obtained from proposed geometric parameters.

Air blast prediction levels at $250 \mathrm{~m}$ when blasting at Pit A for varying cooperate charges have been modeled and shown in Figure 6. For the range of cooperate charges $(40-100 \mathrm{~kg} / \mathrm{hole})$, the predicted air blast levels at $250 \mathrm{~m}$ using Ollofson [12] and Persson et al. [13] and; Holmberg and Persson [14] models are below the regulatory threshold values of $117 \mathrm{~dB}(\mathrm{~L})$ for residential community.

\section{Conclusions and Recommendations}

The predictive blast impacts assessment of the proposed Pit A is based on the proposed drill and blast geometric parameters. The associated predictive impact models could be employed for future planning of the mine. The modeling of the fly rock, ground vibration and air blast impacts for blasting operations at Pit A using the proposed geometric parameters and existing geology demonstrated compliance with the mine's established clearance buffer zone as follows:

1) The predicted maximum fly rock throw distance of $235 \mathrm{~m}$ falls within the 250 $\mathrm{m}$ clearance buffer zone established by managements of the mine;

2) The maximum predicted PPV at $250 \mathrm{~m}$ using Gustaffson model $(2.00 \mathrm{~mm} / \mathrm{s})$ conforms to the regulatory threshold of $2 \mathrm{~mm} / \mathrm{s}$. The predicted PPV using the USBM model is $2.44 \mathrm{~mm} / \mathrm{s}$ at $250 \mathrm{~m}$ but $1.97 \mathrm{~mm} / \mathrm{s}$ at $300 \mathrm{~m}$; and

3) Based on historic data on cooperate charges, for the average cooperate charge of $53 \mathrm{~kg} / \mathrm{hole}$, the estimated air blast at $250 \mathrm{~m}$ from blasting at Pit A, $114.7 \mathrm{~dB}$ $(\mathrm{L})$, is lower than the regulatory threshold of $117 \mathrm{~dB}(\mathrm{~L})$. Also, based on Ollofson [12] and Persson et al. [13] and; Holmberg and Persson [14] air blast prediction models, the predicted air blast levels at $250 \mathrm{~m}[112 \mathrm{~dB}(\mathrm{~L})$ and $114.5 \mathrm{~dB}(\mathrm{~L})$ respectively] from Pit A were below the $117 \mathrm{~dB}(\mathrm{~L})$ regulatory thresholds.

The prediction models and the predictive values at $250 \mathrm{~m}$ from the proposed Pit A are based on the proposed geometric drill and blast parameters and associated single-hole firing cooperate charges of $41.1 \mathrm{~kg} / \mathrm{hole}$ for the oxide rock zones, $42.2 \mathrm{~kg} / \mathrm{hole}$ for the transition rock zones and $44.9 \mathrm{~kg} / \mathrm{hole}$ for the fresh rock zones of the pit. These evaluated cooperate charges should be used during the planning of the blasting operations of XYZ Mine. To ensure practical conformity to these predictions, the maximum cooperate charges together with good 


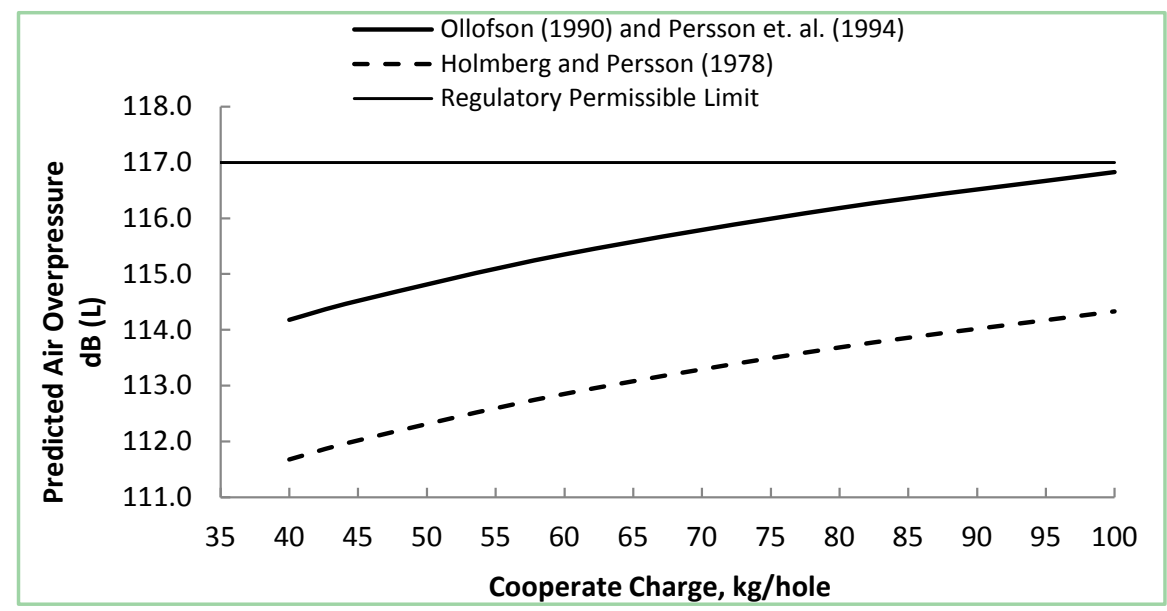

Figure 6. Prediction models for air blast at $250 \mathrm{~m}$ when blasting at Pit A.

charging practices should be strictly adhered to. Due to known scattering of NONEL explosives in initiation systems, electronic initiation systems are recommended for blasting at Pit A. Finally, the predicted impact values need to be validated with collected field data during actual mining of Pit A.

\section{Acknowledgements}

Special acknowledgement to Prof Newton Amegbey, who has been working on impact predictions and will always ensure that, impact predictions are meticulously checked before they are released to the final user.

\section{References}

[1] L.I.2177 (2012) Minerals and Mining (Explosives) Regulations, 2012. In: M.C.o. Ghana, Ed., Ghana Publishing Company Ltd, Accra.

[2] Amegbey, N.A. and Afum, B.O. (2014) Atmospheric Pollutants Diffusion Studies. Ghana Manganese Company (GMC), Tarkwa.

[3] Afum, B.O. and Temeng, V.A. (2015) Reducing Drill and Blast Cost through Blast Optimisation-A Case Study. Ghana Mining Journal, 15, 50-57.

[4] Cunningham, C.V.B. (1983) The Kuz-Ram Model for Prediction of Fragmentation from Blasting. In: Holmberg, R. and Rustan, A., Eds., First International Symposium on Rock Fragmentation by Blasting, Luleå University of Technology, Lulea, Vol 2, 439-453.

[5] Cunningham, C.V.B. (1987) Fragmentation Estimations and the Kuz-Ram Model-Four Years on. In: Fourney, W.L. and Dick, R.D., Eds., Second International Symposium on Rock Fragmentation by Blasting, Keystone, Colorado, Bethel CT: SEM, 475-487.

[6] Cunningham, C.V.B. (2005) The Kuz-Ram Fragmentation Model-20 Years on. In: Holmberg, R., et al., Eds., Brighton Conference Proceedings 2005 by the European Federation of Explosives Engineers, Brighton, 201-210.

[7] Amegbey, N.A. (2010) Assessment of the Impact of Blasting Activities at Pit C North of Ghana Manganese Company (GMC) on Tarkwa Banso Commnunity. Ghana Manganese Company (GMC), Tarkwa. 
[8] Amegbey, N.A., Yormekpe-Agbenu, S.K. and Akayuli, C.F. (2010) Blasiting Standards for Ghanaian Mining Industry. First Biennial UMaT International Conference on Mining \& Mineral Processing, Tarkwa, 4-7 August 2010, 40-53.

[9] Dowding, C.H. (1996) Construction Vibration. Prentice Hall Inc., Eaglewood Cliffs.

[10] Lundborg, N. (1981) The Probability of Fly Rock. Swedish Detonic Research Foundation, Stockholm.

[11] Rau, G.R. and Wooten, D.C. (1980) Environmental Impact Analysis Handbook. McGraw Hill Book Company, New York City.

[12] Ollofson, S.O. (1990) Applied Explosives Technology for Construction and Mining. Applex Publisher, Arla.

[13] Persson, P.A., Holmberg, R. and Jaimin, L. (1994) Rock and Explosives Engineering. CRC Press, Boca Raton.

[14] Holmberg, R. and Persson, G. (1978) Fly Rock and Air Shock Waves in Blasting. Swedish Detonic Research Foundation, Stockholm. 